\title{
Illegal Market of Medicines in Cabo Verde: Characterization for Action
}

\section{Carla Djamila Reis*, Eduardo Jorge Tavares and Jailson Jesus Martins}

Agência de Regulação e Supervisão de Produtos Farmacêuticos e Alimentares (ARFA), Praia, Cape Verde

\begin{abstract}
Background: Medicines contribute to improve survival and quality of life around the world. However, inequities in access to healthcare, combined with advances in industrial technologies enabled the expansion of illegal market of medicines. This is a serious risk to health of populations and health systems because it is highly permeable to counterfeit, falsified, spurious and substandard medicines. The illegal market seems to be increasing becoming a health, social and economic problem in Africa.
\end{abstract}

Purpose: (1) To collect data regarding illegal market of medicines in Cabo Verde to assess the proportion; (2) To know the best-selling medicines; (3) To identify reasons for using it and (4) To identify determinants factors.

Method: A survey study conducted using a stratified sampling plan that included 2206 individuals (95\% confidence level, $5 \%$ sampling error). The database and analysis done using Statistical Package for Social Sciences, version 20.0 (SPSS Inc).

Results: More than $25 \%$ of population purchase medicines in illegal market and the capital (Praia) reach $38.9 \%$. The most sold were paracetamol (50.45\%), ibuprofen (20.18\%) and amoxicillin (17.10\%). The main reason appointed was proximity. $61.2 \%$ knows it may be counterfeit but is not aware of the associated risks. For $36.3 \%$ information given by sellers is not clear. Determinants factors are income and age of individuals.

Conclusion: There is no perception of risk in purchasing medicines on illegal market. There is a need for an integrated preventive and repressive approach that includes coordinated intervention of stakeholders and covers further studies, awareness sessions on pharmacovigilance and rational use of medicines addressed to healthcare professionals and citizens.

Keywords: Illegal market of medicines; Illicit sale of medicines; Cabo Verde; Public health; Access to medicines

\section{Introduction}

The increase of innovator medicines with high levels of effectiveness data has contributed to the improvement of the survival and quality of life of populations around the world. However, the inequities in wealth and access to healthcare, combined with advances in industrial and information technologies enabled a new area of expansion of illegal business: selling medicines outside of legal channels.

The illegal sale of medicines is a serious risk to the health of populations and for sustainable development of health systems. The illegal circuit is highly permeable to the distribution of counterfeit, falsified, spurious and substandard medicines [1]. Estimated to generate more than 55 billion euros per year, the proportion of medicine traffic varies from a country to another from $1 \%$ in industrialized countries with a regulated and controlled distribution system to $60 \%$ of medicines in some developing countries [2].

From 2000 to 2006 , the illegal medicines market increased by $800 \%$. Authorities estimate 800.000 deaths caused by these medicines during this period and that $10 \%$ of all medicines in the world are counterfeit. Counterfeiting and sale of medicines is a profitable activity, affects all therapeutic class of medicines, with less risk of repression by the police authorities than the illegal drugs and directly linked to international criminal organizations [3].

The rise of illegal market seems to be increasing in developing countries becoming a dramatic health, social and economic problem that causes many deaths each year in Africa. However, it has received little scientific interest from researchers and health planners [4]. Published studies for African countries[1,5,6] refers that better accessibility to medicines in primary health care structures would give an alternative to populations and be more effective than mere repression against illegal sellers. According to the author of a research carried out in Dakar (Senegal), this illegal sale must be understood in its social context before taking repressive measures [6].

Cabo Verde is a 40-year-old approximately half-million archipelagic African country. Despite the national production, the country is dependent on the international supply of pharmaceuticals done through one public importer. The problem of the illegal sale of medicines is becoming visible but there are neither studies nor specific information. Illegal market, highly permeable to the distribution of counterfeit medicines, entails serious risks related to the lack of information about origin, storage and distribution conditions with the potential to affect the stability of medicines and to add the absence of a health care professional to assume his role in diagnosis, prescribing and dispensing. Additionally, medicines available through this path has added potential for adverse drug reactions (ADRs) and increased costs for health systems for the delay in proper treatment. As a country that has to protect the significant and ongoing gains achieved in health indicators despite limited resources, it is crucial to characterize the problem and to identify the main predisposing factors to overcome the increase of this public health problem.

*Corresponding author: Carla Djamila Reis, Pharmacist, Master in Pharmaceutical Regulation, Agência de Regulação e Supervisão de Produtos Farmacêuticos e Alimentares (ARFA) Praia, Cape Verde, WestAfrica, Tel: 2382626410; E-mail: djamila.reis@arfa.gov.cv

Received August 27, 2015; Accepted September 14, 2015; Published September 21, 2015

Citation: Reis CD, Tavares EJ, Martins JJ (2015) Illegal Market of Medicines in Cabo Verde: Characterization for Action. J Pharmacovigil 3: 178. doi:10.4172/23296887.1000178

Copyright: $\odot 2015$ Reis $C D$, et al. This is an open-access article distributed unde the terms of the Creative Commons Attribution License, which permits unrestricted use, distribution, and reproduction in any medium, provided the original author and source are credited. 
Citation: Reis CD, Tavares EJ, Martins JJ (2015) Illegal Market of Medicines in Cabo Verde: Characterization for Action. J Pharmacovigil 3: 178. doi:10.4172/2329-6887.1000178

Page 2 of 5

In this context, as a start-up to establish a pharmacovigilance system, a survey was conducted to collect data on the illegal purchase of medicines to identify the strategic lines to combat the problem. More specifically the objectives were (1) To assess the proportion of the population that consumes medicines from the illegal market, (2) To identify the geographical distribution in the country, (3) To knowing the best-selling medicines and (4) To identify the reasons for acquisition on the illegal market.

\section{Methodology}

\section{Population}

The study, conducted by the Agency for Regulation and Supervision of Pharmaceutical and Food (ARFA) in 2012, targeted the resident population in Cabo Verde aged over 18 years at the time of the survey.

\section{Sample}

The sample was scaled separately to the island of Santiago, where $55.72 \%$ of the population lives and where there is perception that the phenomenon of illegal sale of medicines is more serious. The sample for Cabo Verde has been designed according to the islands stratified sampling plan (Table 1) and the sample for Santiago according to the municipality stratified sampling plan (Table 2), using the ratio as the main estimator.

The sample size with 95\% confidence level, $5 \%$ relative error and $50 \%$ variance was 1528 individuals for Santiago and 2206 individuals nationally.

\section{Statistical analysis of the data}

Data analysis was performed using SPSS version 20 and excel 2010 version.

The methods of statistical inference were used to extrapolate the results obtained in the sample to the target audience after calculating point estimates of indicators for a $95 \%$ of confidence interval.

Chi- Square association test was performed to identify the independence of variables under study and to measure the intensity of the association between variables. Statistical significance was set at the level of $5 \%$.

Automatic rules for database validation were used during the data analysis phase. Measures to ensure participants confidentiality were established and the study was submitted to the National Committee for Ethics in Research for Health (CNEPS), as established by Decree-Law No. 26/2007, of July 30 .

\section{Results}

\section{Characterization of the population}

Most of the study population was female (65.9\%), the average age of the study population was 40.2 years and more than $50 \%$ of the surveyed population had 19-40 years old.

As for the country distribution, the sample of the study had greater weight in Praia (26.9\%) and São Vicente (15.5\%), the largest population centers.

The population was also characterized as to education and income level where the majority (43.3\%) had basic level of education (first 4 years education) and $29.8 \%$ high school. Over $50 \%$ of the surveyed population earned an income between 10 to 30.000 capeverdian escudos that correspond to 90.7 to 272 euros.

The results of this study showed that approximately one in four Cabo Verde inhabitants (25.6\%) purchase medicines outside the legal circuit representing a total of 125526 Cabo Verde habitants (Table 3) and that the Praia municipality is the most problematic reaching $38.9 \%$ (Table 4).

According to the results, more than $50 \%$ of the respondents appointed the distance to the pharmacy as the main reason for using the illegal market followed by the price of medicines (Figure 1). As for the periodicity, $23.8 \%$ of people use this market one in two times they need to acquire medicines (Figure 2).

About $71.4 \%$ of the population that uses illegal market has a perception that the conditions of sale are reasonable and $61.2 \%$ of the population declares that medicines may be counterfeit, but is unaware of the risks involved. When questioned about clarity of information given, the majority considers it reasonable but more than $1 / 3$ of respondents (36.3\%) think it is not clear.

Regarding the origin of the medicines, $79.3 \%$ of the population involved did not know the country where the medicine comes from although $14.9 \%$ identifies medicines from the national producer.

The most sold medicines in the illegal market were paracetamol (50.45\%) followed by ibuprofen (20.18\%) and amoxicillin (17.10\%) (Figure 3). Concerning the effects of medicines, $2.1 \%$ of respondents identified adverse effects and $9.0 \%$ describe lack of effect. As for the point of sale, the shop/grocery has been identified as the most common site, reaching $65 \%$.

\section{Discussion}

The results of the study showed that approximately one in four Cabo Verde inhabitants purchases medicines outside the legal circuit (25.6\%), representing a total of 125.526 Cabo Verde inhabitants, and

\begin{tabular}{|c|c|c|}
\hline Islands & Population $^{1}$ & Sample \\
\hline Santo Antão & 43915 & 137 \\
\hline S. Vicente & 76107 & 237 \\
\hline Sal & 25657 & $80 \mathrm{c}$ \\
\hline Boavista & 9162 & 29 \\
\hline Maio & 6952 & 22 \\
\hline Santiago & 273919 & 1528 \\
\hline Fogo & 37051 & 115 \\
\hline Brava & 5995 & 19 \\
\hline Total & $\mathbf{4 9 1 5 7 5}$ & $\mathbf{2 2 0 6}$ \\
\hline
\end{tabular}

${ }^{1}$ According to 2010 Census Data

Table 1: National sample size.

\begin{tabular}{|c|c|}
\hline Santiago Municipalities & Population $^{\mathbf{1}}$ \\
\hline Tarrafal & 18565 \\
\hline Santa Catarina & 43297 \\
\hline Santa Cruz & 26609 \\
\hline Praia & 132317 \\
\hline S. Domingos & 13686 \\
\hline Calheta de S. Miguel & 15648 \\
\hline S. Salvador do Mundo & 8677 \\
\hline S. Lourenço dos Órgãos & 7388 \\
\hline Ribeira Grande de Santiago & 7732 \\
\hline Total & $\mathbf{2 7 3 9 1 9}$ \\
\hline
\end{tabular}

${ }^{1}$ According to 2010 Census Data

Table 2: Sample size for Santiago Island. 
Citation: Reis CD, Tavares EJ, Martins JJ (2015) Illegal Market of Medicines in Cabo Verde: Characterization for Action. J Pharmacovigil 3: 178. doi:10.4172/2329-6887.1000178

Page 3 of 5

\begin{tabular}{|c|c|c|c|c|}
\hline Island & $\mathbf{p}(\%)$ & Absolute error sampling & \multicolumn{2}{|c|}{ Confidence Interval 95\% } \\
\hline Santo Antão & 6.6 & 4.2 & 2.4 & 10.8 \\
\hline São Vicente & 24.2 & 5.5 & 18.7 & 29.8 \\
\hline São Nicolau & 0.0 & ND & ND & ND \\
\hline Sal & 6.3 & 5.3 & 0.9 & 11.6 \\
\hline Boa Vista & 3.3 & 6.5 & 0.0 & 9.9 \\
\hline Maio & 31.8 & 19.9 & 11.9 & 51.7 \\
\hline Santiago & 35.4 & 2.4 & 33.0 & 37.8 \\
\hline Fogo & 6.1 & 4.4 & 1.7 & 10.5 \\
\hline Brava & 15.8 & 16.8 & 0.0 & 32.6 \\
\hline Total (National) & 25.6 & 1.7 & 23.8 & 27.3 \\
\hline
\end{tabular}

Table 3: National illegal market of medicines.

\begin{tabular}{|c|c|c|c|c|}
\hline Municipalities & $\mathrm{p}(\%)$ & $\begin{array}{l}\text { Absolute error } \\
\text { sampling }\end{array}$ & \multicolumn{2}{|c|}{ Confidence Interval $95 \%$} \\
\hline Tarrafal & 22.0 & 7.8 & 14.2 & 29.8 \\
\hline Santa Catarina & 31.8 & 5.9 & 26.0 & 37.7 \\
\hline Santa Cruz & 51.4 & 8.1 & 43.3 & 59.4 \\
\hline Praia & 38.9 & 3.5 & 35.4 & 42.5 \\
\hline São Domingos & 6.5 & 5.5 & 1.0 & 12.0 \\
\hline São Miguel & 49.4 & 10.5 & 38.9 & 60.0 \\
\hline São Salvador do Mundo & 19.6 & 11.6 & 8.0 & 31.1 \\
\hline São Lourenço dos Órgãos & 19.5 & 12.2 & 7.3 & 31.8 \\
\hline Ribeira Grande de Santiago & 27.7 & 12.9 & 14.8 & 40.5 \\
\hline Total (Santiago) & 35.4 & 2.3 & 33.1 & 37.7 \\
\hline
\end{tabular}

Table 4: Illegal market of medicines in Santiago Island.

the municipality of Praia, the capital, is the most problematic.

The proximity to the pharmacy or to health facilities were identified as the main reason for buying in the illegal market, which appears to be related to the pharmaceutical coverage. However, more studies are needed to explain this result considering that the municipalities where there were more purchasing medicines outside the legal circuit were those who have most pharmaceutical coverage and which do not correspond to the poorest municipalities in the country. Praia, the largest urban center of the country with a population of 132317 , has an incidence of $38.9 \%$, has 9 pharmacies and S. Vincente with a population of 76107 has 6 pharmacies. Maybe, the influence of lifestyle in urban centers where people tend to avoid the delays for obtaining a prescription and dispensing of the medication, where the urban transport is difficult and where there is a false perception of knowledge that promotes the self-medication, could be considered as a hypothesis of explanation.

The second reason identified was the price where the perception of the lowest price comes from the fractionating of medicines, important in a country where most of the population is poor.

Considering the proportion of the population surveyed using the illegal market, the perception that the conditions of sale were reasonable $(71.4 \%)$ and the percentage that assumes knowing the medicines may be counterfeit but unaware of the risks that this implies (61.1\%), it is evident the need for information campaigns among the population.

Among the most sold medicines identified was paracetamol, ibuprofen and amoxicillin, the latter being a particular risk factor for the world evidence of increased resistance to antibiotics but with recognized risk factors associated with misuse of any of them.

The level of adverse effects and lack of effect identified maybe be influenced by the reduced awareness of the risks and by the bias of avoiding to assume an undesirable response as consequence of a behavior known to be incorrect as using the illegal market.

To support the identification of coherent strategic guidelines and the adoption of comprehensive intervention and integrated measures adapted to the national reality, it is important to identify the determinants for this behavior. Therefore, the relation was tested between the acquisition and education level, income and age.

Regarding education, for statistical significance level of 5\% there is a weak relationship (Table 5). The weak relationship found between the education level and use of illegal market and the country's data on the reduction of illiteracy seems to indicate that formal education is different from health literacy. Therefore, informative campaign and, most of all, impact assessments of those campaigns are needed.

It was found that, for statistical significance level of $5 \%(\mathrm{p}=0.000)$, buying on the illegal market depends on the income level of individuals (Table 6). The higher the level of income of individuals less likely it will be to buy medicines on the illegal market and specifically more than $85 \%$ of the approximately $25 \%$ of Cabo Verde inhabitants who use illegal market have income less than 30.000 escudos (272 euros).

The dependency analysis made with age for statistical significance level of $5 \%(p=0.000)$ identifies that over $45 \%$ of users were between 15 to 35 years, then $18.3 \%$ were 36 to 45 years of age and aged between 75 
Citation: Reis CD, Tavares EJ, Martins JJ (2015) Illegal Market of Medicines in Cabo Verde: Characterization for Action. J Pharmacovigil 3: 178.

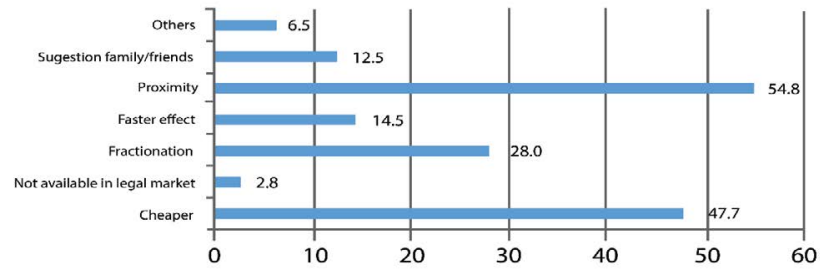

Reasons to use the illegal market (\%)

Figure 1: Reasons to use the illegal market.

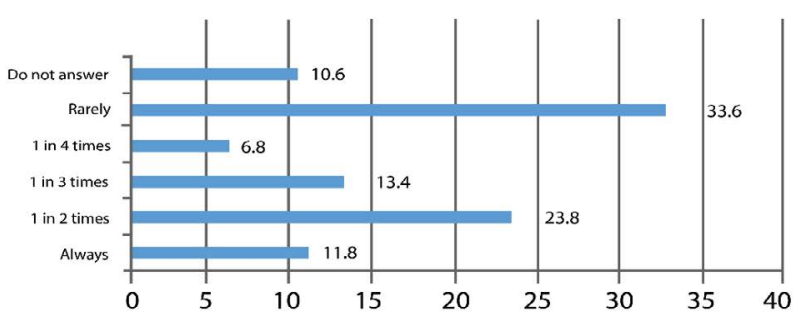

Purchase frequency in the illegal market $(\%)$

Figure 2: Purchase frequency in the illegal market.

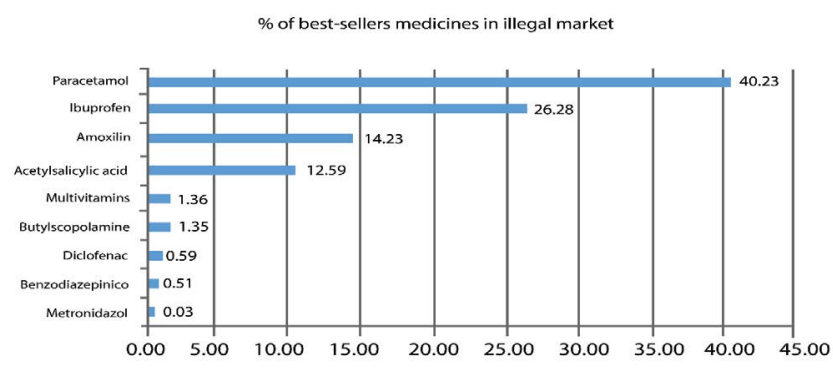

Figure 3: Best-sellers medicines in illegal market. years and above were $1.5 \%$. There is a relationship where the younger has bigger probability of using the illegal market. There is a strong relationship that persists whatever the assumed error (Table 7).

\section{Conclusion}

As determinants, it was found that buying on the illegal market is related to low income and young age. This is very important information for a poor and young country were more than $25 \%$ of population is poor and $54.5 \%$ of the population is under 25 years. One of the responses to the survey reflects that there is no perception of risk in purchasing medicines outside the legal market. This information would be a message taught by health care professionals. Concerning the effects of medicines, further studies are needed with laboratory support. The recommendation is to proceed with diagnose to support the project for a pharmacovigilance system measuring the awareness and knowledge of health care professionals regarding pharmacovigilance and measuring the impact of information campaign addressed to the public.

In parallel, it is crucial to develop a national strategic plan to combat the illegal sale of medicines in Cabo Verde including measures in five main areas: legislation/regulation, cooperation, enforcement, technology and communication. The structure of the plan should follow a phased development scheme, with participation of all stakeholders from regulators, health, education, police, customs, inspection, health care professionals' organizations and consumers. It should include preventive approach (i) Increasing pharmaceutical coverage, (ii) Regulating price and fractioning of medicines where it fits, and (iii) Focus on awareness sessions to health care professionals and population, but without neglecting the repressive and punitive measures.

\section{Acknowledgements}

To the Agency for Regulation and Supervision of Pharmaceutical and Food (ARFA) as sponsor of the study and permission to use the information

Nadege Fortes for the assistance with all the planning, training of inquirers supervision and the inquiry.

Larissa Serdukova for the statistical support during inquiry planning.

\begin{tabular}{|c|c|c|c|}
\hline & Value & df & Asymp. Sig. (2-sided) \\
\hline Pearson Chi-Square & $9,751 a$ & 4 & ,045 \\
\hline Likelihood Ratio & 10,717 & 4 & ,030 \\
\hline Linear-by-Linear Association & ,836 & 1 & ,361 \\
\hline $\mathrm{N}$ of Valid Cases & 2184 & & \\
\hline
\end{tabular}

a: 0 cells $(0,0 \%)$ have expected count less than 5 . The minimum expected count is 1,314

Table 5: Chi-Square Test for relation between the use of illegal market of medicines and education.

\begin{tabular}{|c|c|c|c|}
\hline & Value & df & Asymp. Sig. (2-sided) \\
\hline Pearson Chi-Square & $57,720 a$ & 4 &, 000 \\
\hline Likelihood Ratio & 63,387 & 4 &, 000 \\
\hline Linear-by-Linear Association & 12,403 & 1 & ,000 \\
\hline $\mathrm{N}$ of Valid Cases & 2143 & & \\
\hline
\end{tabular}

a: 0 cells $(0,0 \%)$ have expected count less than 5 . The minimum expected count is 1,980

Table 6: Chi-Square Test for relation between the use of illegal market of medicines and income. 
Citation: Reis CD, Tavares EJ, Martins JJ (2015) Illegal Market of Medicines in Cabo Verde: Characterization for Action. J Pharmacovigil 3: 178. doi:10.4172/2329-6887.1000178

Page 5 of 5

\begin{tabular}{|c|c|c|c|}
\hline & Value & df & Asymp. Sig. (2-sided) \\
\hline Pearson Chi-Square & $65,569 a$ & 6 &, 000 \\
Likelihood Ratio & 74,325 & 6 &, 000 \\
Linear-by-Linear Association & 54,207 & 1 &, 000 \\
N of Valid Cases & 2179 & & \\
\hline
\end{tabular}

a: 0 cells $(0,0 \%)$ have expected count less than 5 . The minimum expected count is 3,130

Table 7: Chi-Square Tests for relation between use of illegal market of medicines and age.

\section{References}

1. Gaudiano MC, Maggio AD, Cocchieri E, Antoniella E, Bertocchi P, et al. (2007) Medicines informal market in Congo, Burundi and Angola: Counterfeit and substandard antimalarial. Malar J 6: 22

2. Taverriti-Fortier C, Pape E, Scala-Bertola J, Tréchot $P$, Maincent $P$, et al. (2015) Counterfeit and Falsified Drugs: An Overview. Therapie 70: 455-464.

3. Hurtado RL, Lasmar MC (2014) Counterfeit and contraband drugs in Brazil: Overview and prospects for preventing their use. Cad Saude Publica 30: 891 895.
4. Rossi C (2013) Monitoring the size and protagonists of the drug market: Combining supply and demand data sources and estimates. Curr Drug Abuse Rev 6: 122-129.

5. Fassin D (1988) Illicit sale of pharmaceuticals in Africa: Sellers and clients in the suburbs of Dakar. Trop Geogr Med 40: 166-170.

6. Fassin D (1986) Illicit sales of drugs in Senegal. Consequences for community health. Bull Soc Pathol Exot Filiales 79: 557-570. 